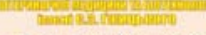

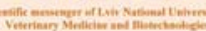
5. Whes: 10 incming

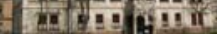

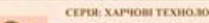

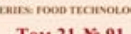

Науковий вісник Дьвівського національного університету ветеринарної медицини та біотехнологій імені С.3. Гжицького. Серія: Харчові технології

\author{
Scientific Messenger of Lviv National University
} of Veterinary Medicine and Biotechnologies.

Series: Food Technologies

UDC 378.1

\title{
Construction of a plan and a section of a building site in the environment of the AutoCAD graphic editor for the virtual learning environment in the Higher School
}

\author{
I.G. Svidrak, O.O. Boiko, A.L. Bespalov \\ National University “Lviv Polytechnic”, Lviv, Ukraine
}

Article info

Received 28.01.2019

Received in revised form 28.02 .2019

Accepted 01.03.2019

National University "Lviv Polytechnic", S. Bandera Str., 12, Lviv, 790013, Ukraine.

Tel.: +38-066-229-50-87 E-mail:svidrak99@gmail.com, Oleksandr.o.boiko@lpnu,ua, anatoliq.bespalov@gmail.com
Svidrak, I.G., Boiko, O.O., \& Bespalov, A.L. (2019). Construction of a plan and a section of a building site in the environment of the AutoCAD graphic editor for the virtual learning environment in the Higher School. Scientific Messenger of Lviv National University of Veterinary Medicine and Biotechnologies. Series: Food Technologies, 21(91), 89-94. doi: 10.32718/nvlvetf9115

During construction for development and design documentation's presentation takes more time, than directly designing. Therefore, actual mean is a execution 's automation of design documentation with using computer graphics. Computer Graphics is a knowledge base for creating, processing, and storing models of geometric shapes and their graphic images by using a computer. A characteristic development 's feature of modern production is its automation, one of the main components which are the systems of automated design (CAD). Those of them that are focused only on solving specific problems, for example, in the production of design documentation, are called local systems. At present, there are many software systems of computer design of varying complexity and purpose. One of the most commonly used graphical system is the AutoCAD. In creating architectural and construction drawings, the process of constructing a plan and cutting the construction site requires a considerable amount of time. Therefore, the using AutoCAD graphical system is relevant for quick and high-quality execution of this work. The method of step-by-step application of AutoCAD commands was developed by the authors for building boundaries of earthworks, horizontals with numeric labels, and also for determining the boundaries of earthworks for excavation and embankment of the site. The squares's grid of the slopes and the linear scale of the drawing are crossed out is used to be given by the variant of the ratio, for the option for simplifying the construction. Similar construction is also used to construct a ramp (access road). In addition, the process of constructing lines of intersection of slopes with each other and with a topographic surface, as well as the process of building the profile of the area and profile of the construction site is shown in the work. After using each of the current AutoCAD commands for demonstration its execute, are given illustration of successive steps for creating a drawing of construction site. The performed work involves the preparation of material for methodically filling the course of computer graphics in a virtual environment, has relevance in the educational process. The results of the presented work are used in the sections of the teaching manual for students of engineering and construction specialties and in the virtual learning environment at the Higher School.

Key words: Computer simulation, graphic editor, virtual learning environment, geometric constructions, construction site.

\section{Побудова плану $\mathrm{i}$ розрізу будівельного майданчика у середовищі графічного редактора AutoCAD для віртуального навчального простору у Вищій школі}

\author{
І.Г. Свідрак, О.О. Бойко, А.Л. Беспалов \\ Наџіональний університет “Львівська політехніка”, м. Львів, Украӥна
}


Під час конструювання на розроблення та оформлення конструкторської документації припадає переважно більше часу, ніж безпосередньо на проектування. Тому актуальне значення має автоматизація виконання конструкторської документації з застосуванням комп ютерної графіки. Комп'ютерна графіка - це галузь знань зі створення, оброблення та зберігання моделей геометричних форм та їхніх графічних зображень з допомогою комп'ютера. Характерною ознакою розвитку сучасного виробництва є його автоматизація, одним з основних компонентів якої є системи автоматизованого проектування (САПР). Ті з них, шзо орієнтовані лише для розв'язання конкретних завдань, наприклад на виготовлення конструкторської документації, називають локальними системами. На теперішній час є чимало програмних систем комп'ютерного проектування різної складності та різних за призначенням. Одною з найпоширеніших у використанні є графічна система АитоСАD. При створенні архітектурно-будівельних креслень процес побудови плану і розрізу майданчика будівельного вимагає значної кількості часу. Тому застосування графічної системи АитоСАD для швидкого та якісного виконання иієї роботи є актуальним. Авторами розроблено методику покрокового застосування команд АитоСАD для побудови границь земляних робіт, горизонталей з числовими позначками, а також для визначення меж земляних робіт для виїмки та насипу майданчика. Використовуючи задані за варіантом співвідношення для спрощення побудов викреслено сітку квадратів нахилів і лінійний масштаб креслення. Також аналогічні побудови застосовано для побудови апарелі (під '̈зної дороги). Крім того, в роботі показано прочес побудови ліній перетину укосів між собою $і$ з топографічною поверхнею, а також прочес побудови профілю місиевості та профілю майданчика будівельного. Після використання кожної поточної команди АитоСАD для демонстрації результату ї̈ виконання наведено ілюстрації послідовних кроків створення креслення майданчика будівельного. Виконана робота передбачає підготовку матеріалу для методичного наповнення курсу комп 'ютерної графіки у віртуальному середовищі, має актуальність у навчальному процесі. Результати иієї роботи використані у розділах навчальнометодичного посібника для студентів інженерно-будівельних спеціальностей та у віртуальному навчальному середовищі у Вищій иколі.

Ключові слова: комп'ютерне моделювання, графічний редактор, віртуальне навчальне середовище, геометричні побудови, майданчик будівельний.

\section{Ветуп}

Одним із основних чинників навчального процесу $\epsilon$ підвищення якості проведення усіх видів занять та застосування у навчальному процесі інтерактивних методів, оскільки вивчення сучасних графічних систем у вищих навчальних закладах пов'язано, крім лекційних та лабораторних занять, з наявністю методичного забезпечення з даної тематики у віртуальному навчальному середовищі ВНЗу.

Метою роботи є підготовка матеріалу для віртуального навчального середовища з курсу комп'ютерної графіки для студентів архітектурно-будівельного напрямку, зокрема "Побудова плану і розрізу майданчика будівельного”.

Завдання. Для виконання графічної роботи поставлене завдання адаптувати покрокову послідовність побудови плану та розрізу майданчика будівельного на площині до інструментальних засобів графічного редактора AutoCAD, що суттєво пришвидшить та підвищіть якість виконання цієї роботи студентами.

\section{Матеріал і методи досліджень}

AutoCAD - це сучасна, відкрита для розвитку система прикладних комп'ютерних програм, яка здатна автоматизувати найрізноманітніші графічні роботи. Пакет AutoCAD дозволяє швидко і точно побудувати креслення, надає зручні й потужні засоби редагувати вже готове креслення. Графічна система AutoCAD практично не має ніяких обмежень. 3 іiі допомогою можна створювати текстову документацію, машинобудівні та архітектурно-будівельні креслення, картографічну документацію, технічні ілюстрації тощо (Volsh et al., 1997; Barchard, 1997).

Можна виділити два підходи до конструювання на основі комп'ютерних технологій. Перший підхід грунтується на двомірній моделі виробу - кресленні, яке конструктор створює на основі уявного образу оригіналу і вже безпосередньо за ним розв'язує геометричні, метричні, позиційні та інші конструкторські за- вдання. В основі другого підходу - комп'ютерна просторова геометрична модель (так звана “твердотільна модель”), яка слугує конструктору основою для розв'язання завдань. На сучасному етапі можливості AutoCAD вельми широкі i набагато перевершують можливості “електронного кульмана”. Його останні версії поєднують як засоби проектування на площині, так і тривимірного моделювання (Onstott, 2017; Omura \& Benton, 2017).

Перший підхід є традиційним, і комп’ютер за такої умови використовують як “електронний кульман”, що дає змогу значно прискорити конструювання і досягти високої якості конструкторської документації. Чільне місце за такого підходу посідає креслення документ, який водночас слугує засобом графічного зображення виробу, основою для розв'язання конструкторських завдань і містить всю інформацію, необхідну для виготовлення та контролю виробу.

Останні версії AutoCAD, так само, як і ранні, оперують однаковим набором елементарних графічних об'єктів, такими як: кола, лінії, дуги і текст, з яких можна створити складніші геометричні форми. Тому побудову майданчика будівельного на площині можна реалізувати на будь-якій доступній версії графічного редактора AutoCAD.

\section{Результати та їх обговорення}

Ділянка місцевості, на якій запроектовано майданчик будівельний, подана горизонталями з числовими позначками 16, 17, .,, 28 (рис. 1) Отже, ліворуч від горизонталі 23 м маємо виїмку, а праворуч - насип.

Приймемо нахил укосів виїмки $i_{6}=1: 1$; нахил укосів насипу $i_{\mathrm{H}}=1: 1,5$; нахил апарелі $i_{\partial}=1: 6$; масштаб 1:200. Отже, інтервал укосів виїмки $l_{\theta}=1$ м; інтервал укосів насипу $l_{H}=1,5$ м; інтервал апарелі $l_{\partial}=6$ м.

Потрібно:

1. Побудувати в плані укоси виїмки та насипу;

2. Побудувати лінії перетину укосів між собою і 3 топографічною поверхнею; 
3. Побудувати профіль I-I топографічної поверхні та майданчика будівельного.

Розглянемо послідовність виконання графічної роботи “Майданчик будівельний”. Для побудови використовуємо графічний редактор AutoCAD англомовної версії 2015.

1. Будуємо план земельної ділянки в заданому масштабі 1:200. Згідно з варіантом завдання наносимо горизонталі топографічної поверхні. Для побудови застосовуємо команду побудови геометричного сплайна - Spline На плані земельної ділянки викреслюємо прямокутний план майданчика будівельного за допомогою команди Rectang i нахиленого в'їзду на нього командою - Line (рис. 1).

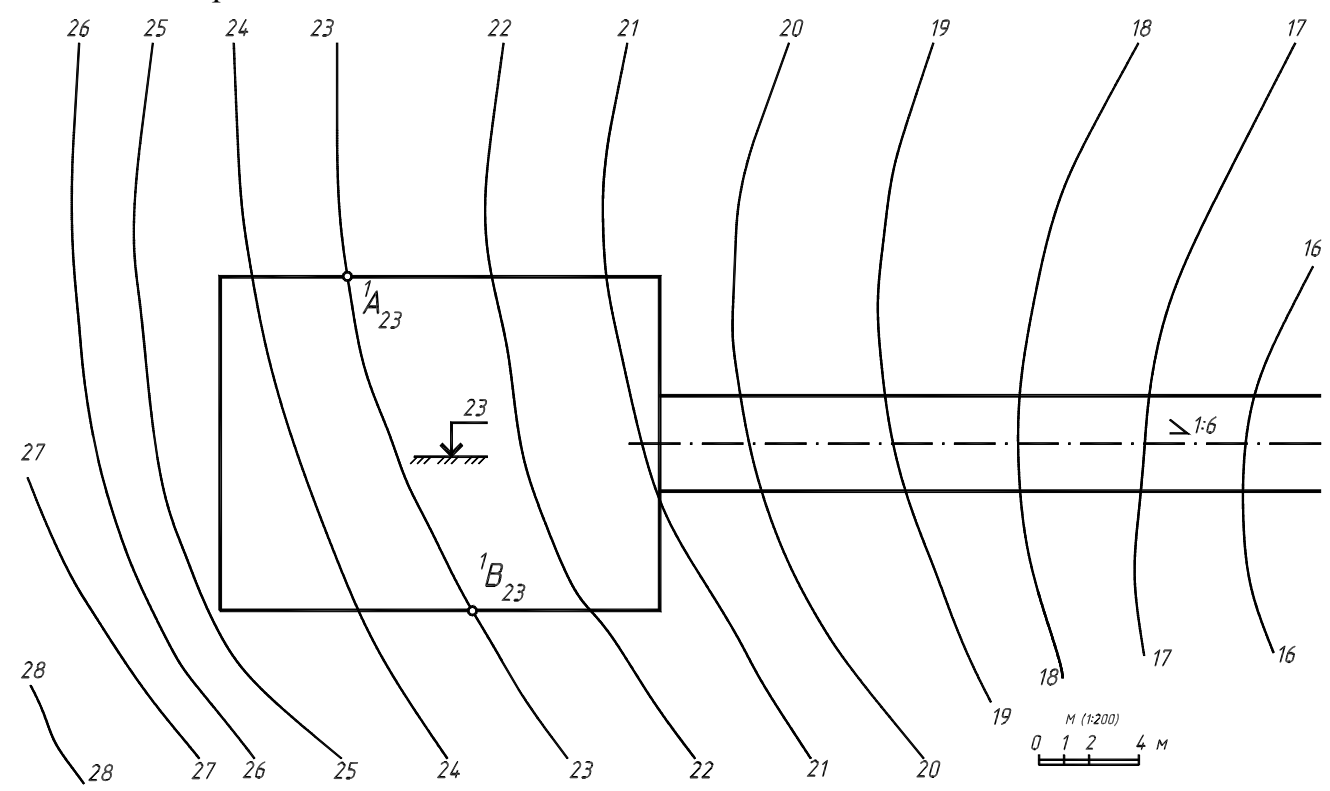

Рис. 1. Прямокутний план майданчика будівельного

2. Визначаємо лінію переходу майданчика будівельного з виїмки у насип. Такою лінією $€$ горизонталь 3 числовою позначкою 23 , тому що майданчик будівельний розташований на висоті 23 м. Відрізок горизонталі ${ }^{1} A_{23}{ }^{1} B_{23}$, розташований між бровками майданчика будівельного, являє собою лінію нульових робіт, а горизонталь 23 називається горизонталлю нульових робіт.

Праворуч від горизонталі 23 розташовані укоси насипу, бо відмітки горизонталей топографічної повеpхні $22,21,20, \ldots, 16$ менші за відмітку горизонталі 23. На цій ділянці місцевості потрібно насипати частину землі.

Ліворуч від горизонталі з числовою позначкою 23 розташовані укоси виїмки, бо відмітки горизонталей топографічної поверхні $24,25, \ldots, 28$ більші за відмітку горизонталі 23. На цій ділянці місцевості частину землі потрібно вибрати.

3. Командою Line будуємо масштаби нахилів, використовуючи сітку квадратів. Сторона квадрату дорівнює різниці числових позначок сусідніх горизонталей, тому приймаємо розмір сторони кожного квадрату рівним 1 м. Лінійний масштаб дорівнює 1:200, тобто 1 мм зображення відповідає 200 мм на місцевості. Розмір зображення, що відповідає 1 м на місцевості згідно $з$ масштабом, приймаємо 5 мм.

Сітку квадратів нахилів з лініями напрямків укосів і лінійний масштаб М 1:200 (рис. 2) розташовуємо на форматі внизу справа (відрізок прямої укосів виїмок 3 нахилом $i_{6}=1: 1$; відрізок прямої укосів насипів з нахилом $i_{H}=1: 1,5$; відрізок прямої апарелі 3 нахилом $\left.i_{\partial}=1: 6\right)$. Таким чином, $l_{b}=5 \mathrm{mм} ; l_{t}=7,5 \mathrm{Mм} ; l_{\partial}=30 \mathrm{mм}$, а на місцевості ці відрізки відповідають інтервалам укосів виїмок - 1 м, насипів - 1,5 м, апарелі - 6 м.

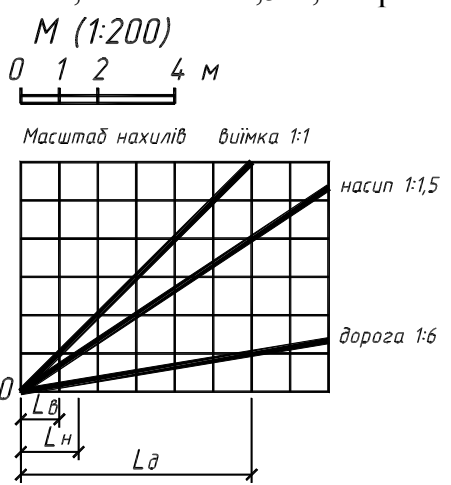

Рис. 2. Сітка квадратів нахилів

4. За допомогою команди Pline будуємо першу горизонталь 24-24 укосів $\alpha, \beta, \gamma$ виїмки, яка міститьсяліворуч від горизонталі 23 м. Отже, маємо три укоси виїмки. Використовуємо команду Offset для побудови подібних горизонталей 25-25, 26-26, 27-27, 28-28 виїмки задаючись інтервалом подібності $-l_{6}=5$ мм.

За допомогою команди MLine перпендикулярно до бровок майданчика горизонтального проводимо проекції масштабів нахилів укосів виїмки, які спрямовані у бік бровок майданчика будівельного. Стрілки проекцій масштабів нахилів ${ }^{1} S$ вказують напрям нахилів укосів майданчика будівельного.

5. Командою Line будуємо лінії взаємного перетину укосів $\alpha, \beta, \gamma$ виїмки. Ці лінії визначаються точками перетину горизонталей укосів 3 однаковими числовими позначками. 
6. Для градуювання проекцій масштабів нахилів ${ }^{1} S_{\delta},{ }^{1} S_{\omega},{ }^{1} S_{\varphi},{ }^{1} S_{\varepsilon}$ укосів чотирьох насипів $\delta, \omega, \varphi, \varepsilon$ майданчика будівельного використовуємо інтервал $l_{\mu}=$ 7,5 мм. Для спрощення побудови застосовуємо команду побудови кола - Circle з координатами центра в точці 0,0 і радіусом 7,5 мм. Надалі командою Сору копіюємо його i вставляємо на кутах майданчика будівельного з боку апарелі (рис. 3). За допомогою команди Pline будуємо першу горизонталь 22-22 укосів насипу майданчика будівельного.

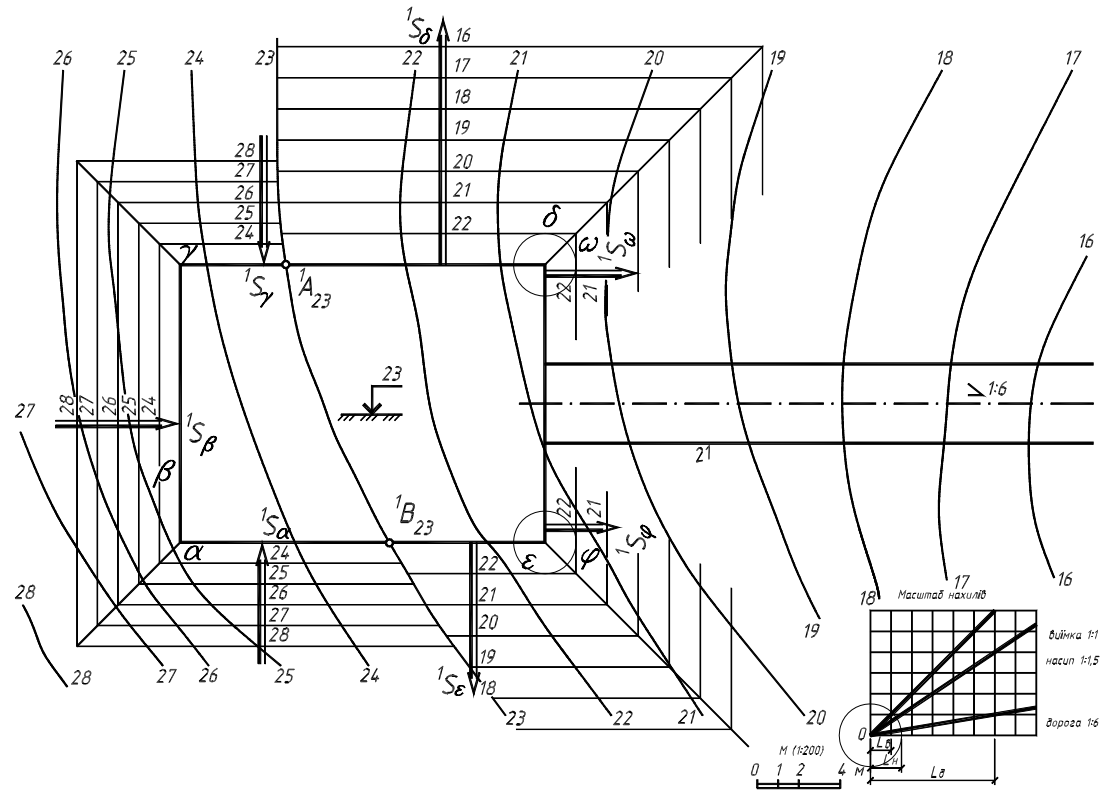

Рис. 3. Горизонталі укосів насипу майданчика будівельного

7. Використовуємо команду Offset для побудови подібних горизонталей 21-21, 20-20, 19-19 апарелі та лінії їх взаємного перетину згідно з п.п. 4, 5. Лінією перетину майданчика будівельного і апарелі є одночасно горизонталь 23-23 апарелі. Посередині апарелі командою Line проводимо штрих-пунктирну лінію, вздовж якої відкладаємо, починаючи від горизонталі 23-23, інтервал $l_{\partial}=30$ мм апарелі та проводимо лінії, перпендикулярні до бровок апарелі. Ці відрізки і $\epsilon$ горизонталями 22-22, 21-21, 20-20, 19-19 апарелі. Над штрихпунктирною лінією наносимо позначення нахилу апарелі: $\angle 1: 6$ (рис. 4).
8. Будуємо укоси апарелі. Укоси апарелі утворені насипанням землі (для заданого варіанту завдання). Укоси апарелі розглядаємо як площини, дотичні до поверхні конуса. Для їх формування використаємо конус, нахил твірних якого дорівнює нахилу укосів майданчика будівельного: $\angle 1: 1,5$. Вершина конуса рухається по бровці апарелі, оскільки маємо дві бровки апарелі, то використовуємо для побудови укосів два конуси. Будуємо горизонталі укосів насипу апарелі. Використаємо конус 3 нахилом твірних до основи $\angle 1: 1,5$ і висотою $1 \mathrm{M}$.

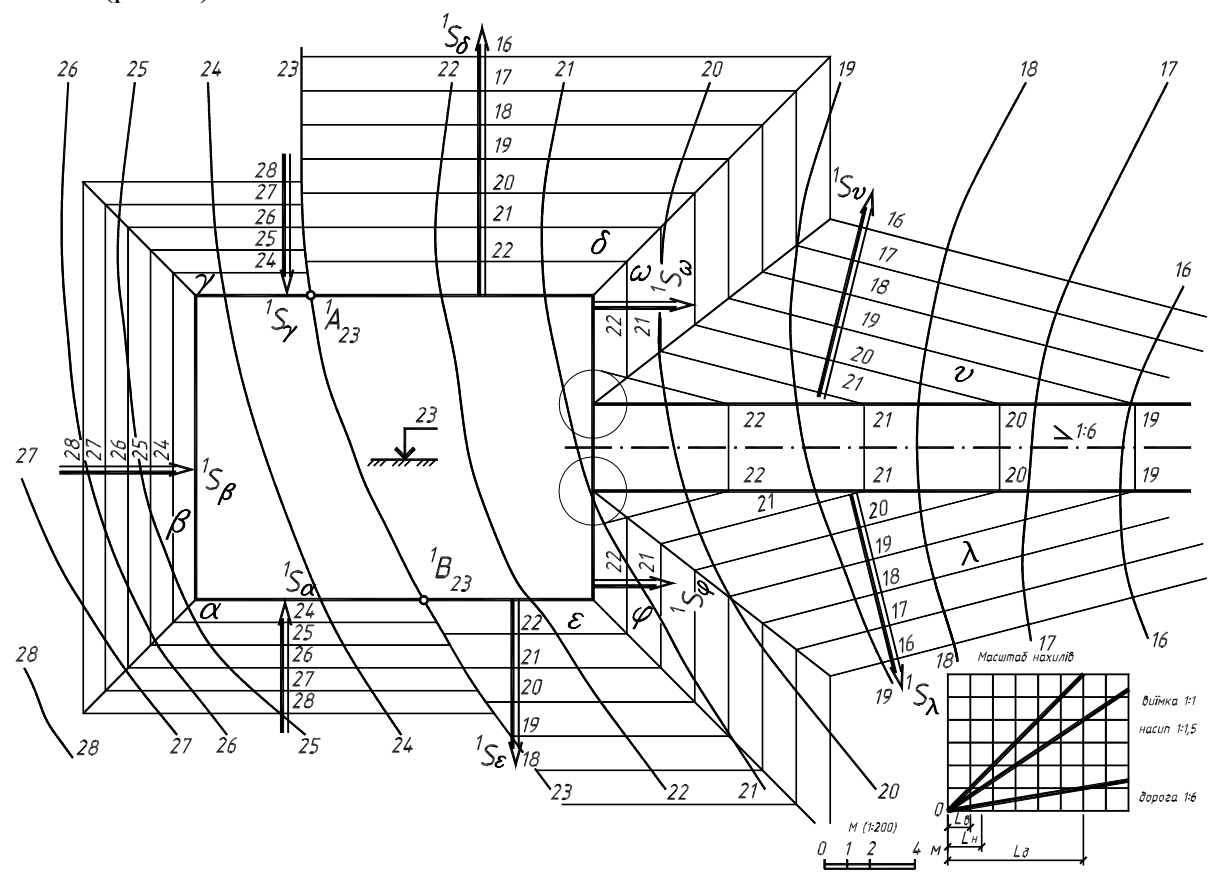

Рис. 4. Позначення нахилу апарелі 
Для заданого нахилу радіус основи конуса дорівнює 7,5 мм. На рис. 4 командою Circle викреслені горизонтальні проекції таких конусів. Вершина кожного конуса - в точках перетину бровок майданчика будівельного і апарелі. Основи конусів - у горизонтальній площині рівня 3 числовою позначкою 22 м. Радіус кола основи кожного конуса дорівнює 7,5 мм. 3 точок 22 брівок апарелі командою Line за допомогою опції об'єктної прив'язки - $\tan$ проводимо відрізки дотичні до кіл основ одного і другого конуса. Напрям дотичних визначає напрям горизонталей площин, що являють собою укоси насипу апарелі. Проградуювавши їх з інтервалом 7,5 мм, через точки 21, 20, 19 проводимо горизонталі 21, 20, 19 укосів насипу апарелі (рис. 4).

9. Командою Line будуємо лінії перетину укосів $v$, $\lambda$ насипу апарелі з укосами $\omega$ i $\varphi$ насипу майданчика будівельного, з'єднавши точки перетину горизонталей $з$ однаковими числовими позначками зазначених укосів насипу апарелі та майданчика будівельного. Перпендикулярно до горизонталей укосів насипу апарелі проводимо проекції масштабів нахилів ${ }^{1} S_{v}$ та ${ }^{1} S_{\lambda}$ укосів v і $\lambda$ насипу апарелі (рис. 4).

10. Визначаємо границі земельних робіт побудовою лінії перетину укосів виїмки та насипу майданчика будівельного i апарелі з поверхнею землі. Лінія перетину укосів являє множину точок перетину горизонталей з однаковими числовими позначками площин укосів виїмки та насипу майданчика будівельного і топографічної поверхні. Командою Donut iз застосуванням опції об'єктної прив'язки - Intersect на перетині лінії укосів виконуємо кільця $\varnothing 2$ мм. Через центри одержаних кілець за допомогою команди Pline 3 опцією Center проводимо ламану лінію. Вона є лінією перетину укосів з топографічною поверхнею (див. рис. 5).

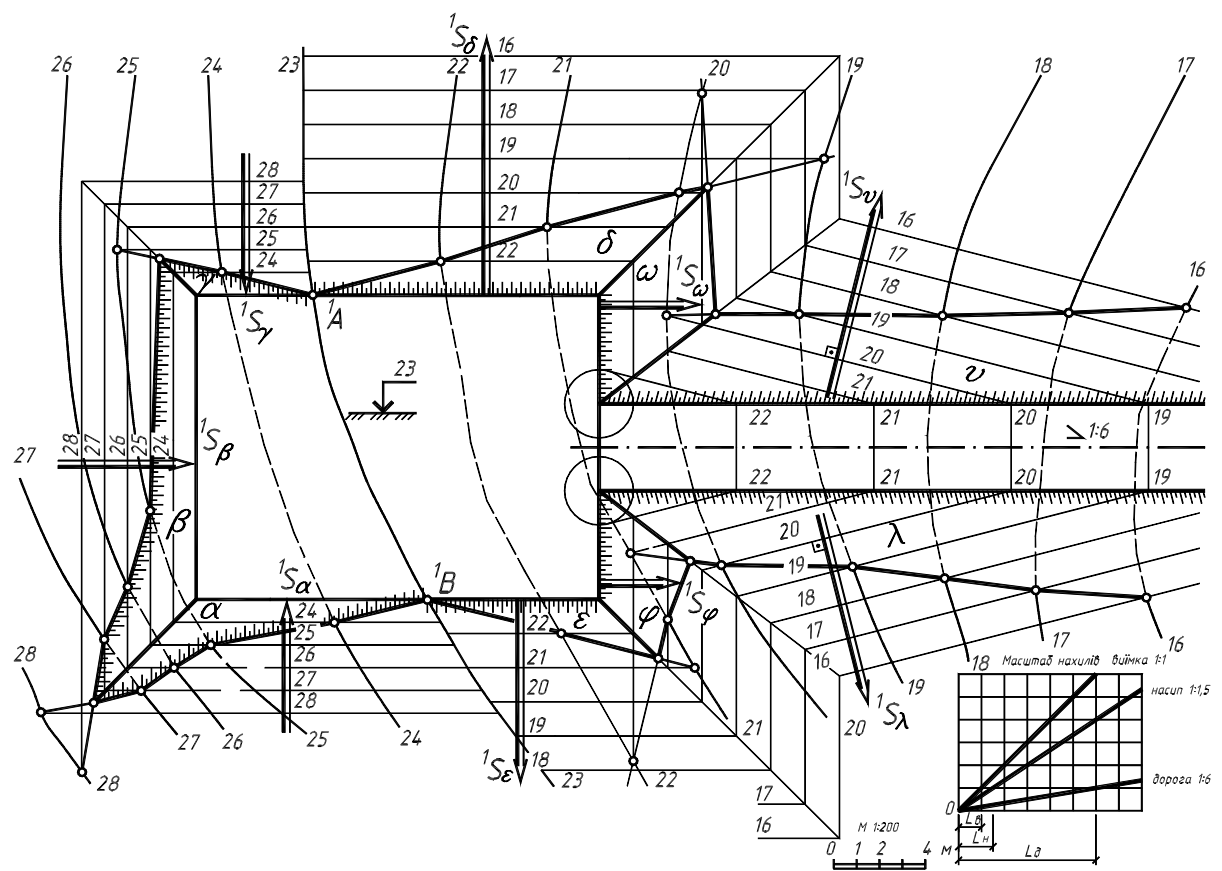

Рис. 5. Лінія перетину укосів з топографічною поверхнею

Точки цієї лінії перетину, що одночасно належать лінії перетину укосів, знаходимо у такій послідовності. 3'єднуємо відрізком точки перетину горизонталей укосу виїмки майданчика будівельного і топографічної поверхні, наприклад горизонталей 24 і 25 з боку укосу $\gamma$ (рис. 5). Відмічаємо точку перетину цього відрізка з лінією перетину укосів $\beta$ i $\gamma$, яка одночасно належить лінії перетину укосів $\beta$ і $\gamma$ з топографічною поверхнею.

При необхідності побудови профілю майданчика будівельного будуємо профіль топографічної поверхні, на який накладаємо власне профіль майданчика будівельного. Профіль місцевості являє собою перетин топографічної поверхні січною площиною. Згідно із завданням на рис. 6 як січну площину використовуємо горизонтально-проекціюючу площину, що задана горизонтальним слідом I-I.

На вільному полі креслення командою Line проводимо дві взаємно перпендикулярні лінії: горизонталь- ну і вертикальну. Січна площина перетинає топографічну поверхню по горизонталях зліва направо 25,24 , 23, 22, 21 і 20, тому на вертикальній лінії відкладаємо командою Donut точки 20, 21, 22, 23, 24, 25, відстань між якими складає 5 мм в масштабі 1:200 або 1 м на місцевості. Через ці точки проводимо горизонталі (рис. 7).

Горизонталь 3 найменшою числовою позначкою, наприклад горизонталь 20 на рис. 7 , називається горизонталлю умовного горизонту. 3 довільної точки горизонталі 20 проводимо вертикальну лінію і присвоюємо їй числову позначку 23 горизонталі нульових робіт. Вліво і вправо від числової позначки 23 відкладаємо на горизонталі 20 відстані до горизонталей 24 i 25 та 22, 21. Відстані вимірюємо за допомогою команди Circle 3 опцією 2Р (побудова кола по двох точкаx) на плані майданчика будівельного по сліду I-I січної площини. 


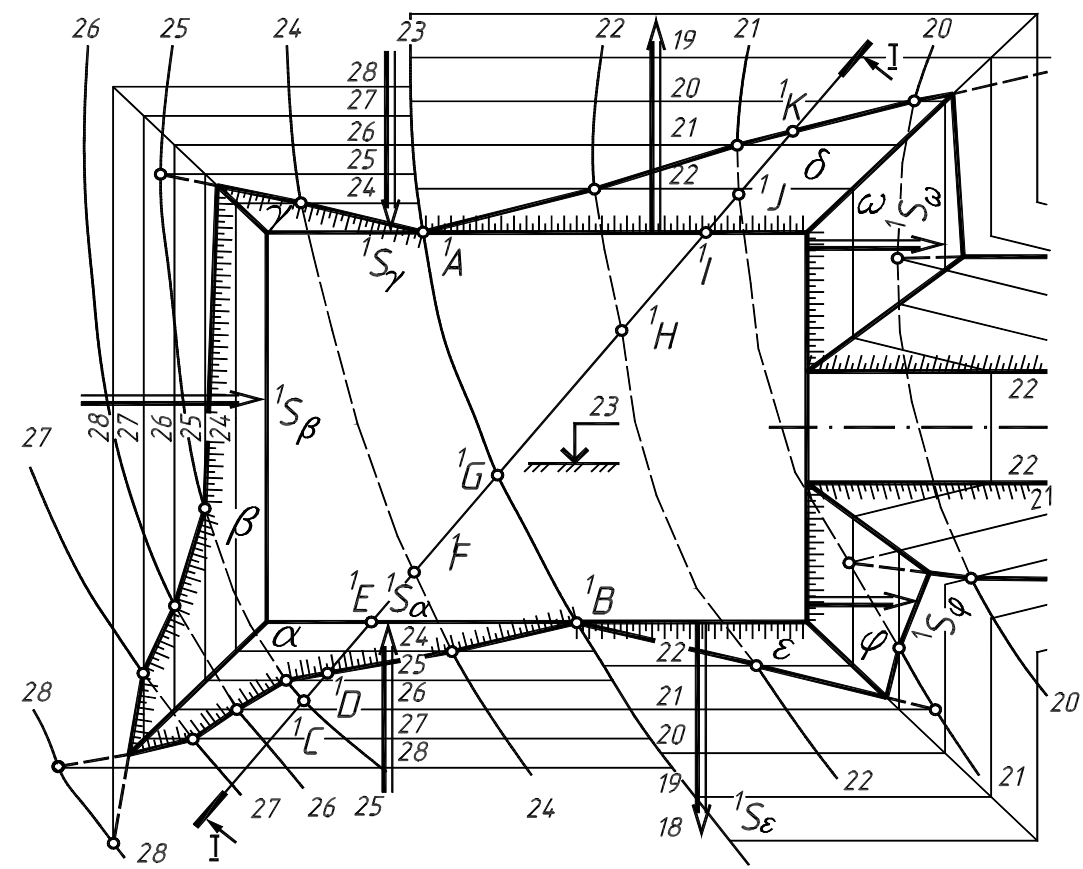

Рис. 6. Перетин топографічної поверхні січною площиною

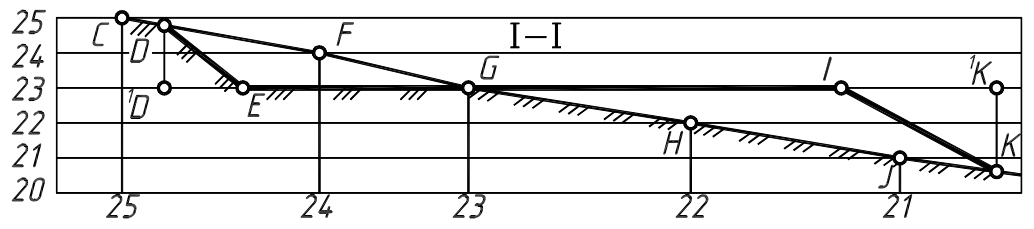

Рис. 7. Профіль місцевості

На перетині вертикальних і горизонтальних ліній 3 однаковими числовими позначками 25 і 25,24 і 24,23 i 23,22 i 22,21 і 21 одержуємо точки $C, F, G, H, J$ топографічної поверхні. Викреслюємо їх командою Donut. Центри кілець 3'єднуємо командою Pline ламаною лінією. Ця лінія являє собою перетин топографічної поверхні січною площиною I-I, тобто профіль I-I топографічної поверхні.

Точка $\mathrm{G}$ належить горизонталі нульових робіт 3 числовою позначкою 23. Ліворуч від неї маємо виїмку, а праворуч - насип. На горизонталі 23 профілю топографічної поверхні відкладаємо вліво, в бік більших числових позначок, виміряний на плані майданчика будівельного (рис. 6) відрізок ${ }^{1} E^{1} G\left(\left|{ }^{1} E^{1} G\right|=\mid E G\right.$ $\mid)$, а вправо, в бік менших числових позначок, - відрізок ${ }^{1} G^{1} I\left(\left.\right|^{1} G^{1} I|=| G I \mid\right)$. Горизонтальна пряма ЕІ є профілем майданчика будівельного (рис. 7).

Будуємо укіс насипу. 3 точки $I$ профілю відкладаємо відрізок $I^{1} K$ довжиною $\left|{ }^{1} I^{1} K\right| .3$ точки ${ }^{1} K$ горизонталі 23 проводимо донизу вертикальну пряму до перетину з лінією профілю топографічної поверхні в точці $K$. Відрізок $I K €$ профілем укосу насипу.

Будуємо укіс виїмки. 3 точки $E$ профілю відкладаємо вліво відрізок $E^{1} D$ довжиною $\left|{ }^{1} E^{1} D\right| .3$ точки ${ }^{1} D$ на горизонталі 23 проводимо догори вертикальну пряму до перетину з лінією профілю топографічної поверхні в точці $D$. Відрізок $E D$ являє собою профіль укосу виїмки майданчика будівельного. Ламана лінія $D E I K$, що складається з відрізків $D E, E I$ і $I K$ прямих, являє собою профіль майданчика будівельного з укосами.

\section{Висновки}

Вивчення студентами матеріалу лабораторних занять 3 курсу інженерної графіки буде краще засвоєно при застосуванні графічного редактора AutoCAD. Тому представлена робота, яка передбачає підготовку методичного матеріалу для наповнення курсу у віртуальному навчальному середовищі, має актуальність у навчальному процесі НУ “Львівська політехніка", а також інших вищих навчальних закладах за інженерними спеціальностями.

Перспективи подальших досліджень. Удосконалення покрокового створення тривимірної візуалізації плаского креслення майданчика будівельного засобами графічного редактора AutoCAD.

\section{References}

Barchard, B. (1997). Vnutrennij mirAutoCAD 14. 14. K.:Izdatel'stvo "DiaSoft" (in Russian).

Volsh, D., Najt, R., \& Velaski, V. (1997). Sekrety AutoCAD 13. K.: Dialektika (in Russian).

Omura, G., \& Benton, B.C. (2017). Installing and Setting Up AutoCAD. Mastering AutoCAD and AutoCAD LT, First Edition. doi: 10.1002/9781119414179.

Onstott, S. (2017). AutoCAD ${ }^{\circledR}$ and AutoCAD LT® Essentials. doi: 10.1002/9781119414124. 